\title{
Returns and Return Premia of Size and Investment Portfolios in Japan-A Conspectus
}

\author{
Chikashi Tsuji \\ Graduate School of Economics, Chuo University, Tokyo, Japan \\ Email: mail_sec_low@minos.ocn.ne.jp
}

How to cite this paper: Tsuji, C. (2021). Returns and Return Premia of Size and Investment Portfolios in Japan-A Conspectus. Modern Economy, 12, 869-877. https://doi.org/10.4236/me.2021.124043

Received: March 22, 2021

Accepted: March 31, 2021

Published: April 27, 2021

Copyright (อ 2021 by author(s) and ScientificResearch Publishing Inc.

This work is licensed under the

CreativeCommons Attribution

International

License (CC BY 4.0).

http://creativecommons.org/licenses/by/4.0/

\section{(c) (i) Open Access}

\begin{abstract}
This article conducts an overview of the performance of Japanese firm sizeand firms' investment-sorted stock portfolios from 1990 to 2020, and we derive the following contributions. First, we find that in our second half sub-period, the size effect is much clearer; while overall, the effect of investment is not so clear, suggesting that the portfolio constructions by firms' investment are not so effective in Japan. Second, as we analyzed the performance of Japanese size- and investment-sorted portfolios using the data, which are in US dollars and for almost 30 years, our findings should be highly meaningful for both industrial practitioners and academic researchers, much deepening our understanding of stock portfolio returns and return premia in Japan.
\end{abstract}

\section{Keywords}

Investment, Japanese Stock Market, Return Premia, Size Effect, Stock Return

\section{Introduction}

In the past literature, there exist many previous studies on the returns of stock portfolios sorted by size- and book-to-market ratios (see, e.g., Fama \& French, 1993, 1995; Tsuji, 2012, 2020). In contrast, there exists little previous research on the returns of firm size- and firms' investment-sorted stock portfolios in Japan; thus, conducting an overview of size and investment-sorted portfolios for Japanese stocks in an effective manner shall be greatly meaningful.

Therefore, based on this, this article newly examines the returns and return premia of size- and investment-sorted portfolios by focusing on the Japanese stock market. The sample period we analyze covers almost 30 years from 1990 to 2020.

As a result, this article derives the following significant contributions. First, we 
find that in our second half sub-period, the size effect is much clearer in Japan; while overall, the effect of investment is not so clear, indicating that the portfolio constructions sorting by firms' investment are not so effectual in Japan. Second, as we examined the performance of size- and investment-sorted Japanese stock portfolios using the data, which are in US dollars and for almost 30 years, our key findings presented in this article should be highly meaningful for both industrial practitioners and academic researchers.

The rest of this article is organized as below. First, Section 2 is a brief related literature review; Section 3 explains our data and research design; Section 4 exhibits our key results; and Section 5 concludes the article.

\section{Short Literature Review}

This section conducts a short review of related literature with our current study. First, Fama and French (1993) developed a representative three-factor empirical asset pricing model, adding size and value factors to the capital asset pricing model. Later, Fama and French (1995) also empirically examined the size and value effects in the US stock market. Afterwards, Fama and French (2015) extended their three-factor model to a five-factor asset pricing model, adding operating profitability and firms' investment factors to their three-factor model.

Recently, Fama and French (2017) tested their five-factor model in international stock markets. Besides, Huang (2019) tested whether the Fama-French five-factor model is robust in the Chinese stock market, and Foye (2018) and Mosoeu and Kodongo (2021) examined the Fama-French five-factor model in emerging stock markets. Most recently, Horváth and Wang (2021) examined the five-factor model in the US by focusing on the period in which there was the effect of the COVID-19.

In contrast, for Japan, using the Japanese data from 1981 to 2005, Tsuji (2012) explored the size- and book-to-market ratio-sorted stock portfolios; and Tsuji (2020) also provided an overview of the size and value effects in Japan for the period from 1990 to 2020 . However, we note that the analysis of the firms' investment, which is a new element for the Fama-French five-factor model, is limited particularly for the Japanese stock market.

As these backgrounds of the past studies clearly show, providing an overview of the performance of Japanese stock portfolios by focusing on the firms' investment effect shall be significantly beneficial for both academic researchers and industry practitioners. Therefore, based on this, in the following sections, this article attempts to conduct an effective overview of the return and return premia of Japanese stock portfolios sorted not only by size but also by firms' investment. 
Panel A. July 1990 to October 2020.

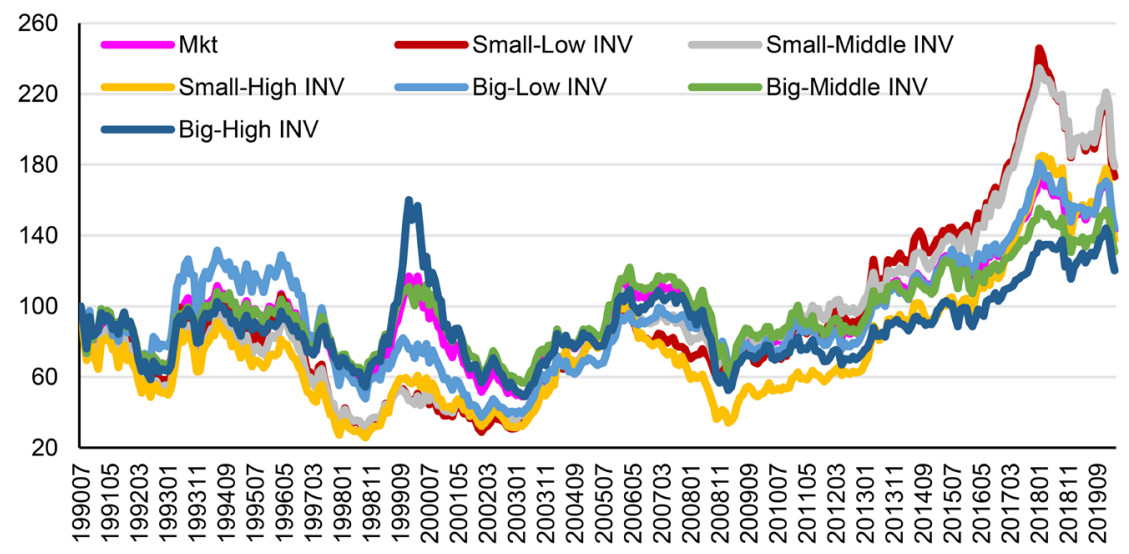

Panel B. July 1990 to December 2005.

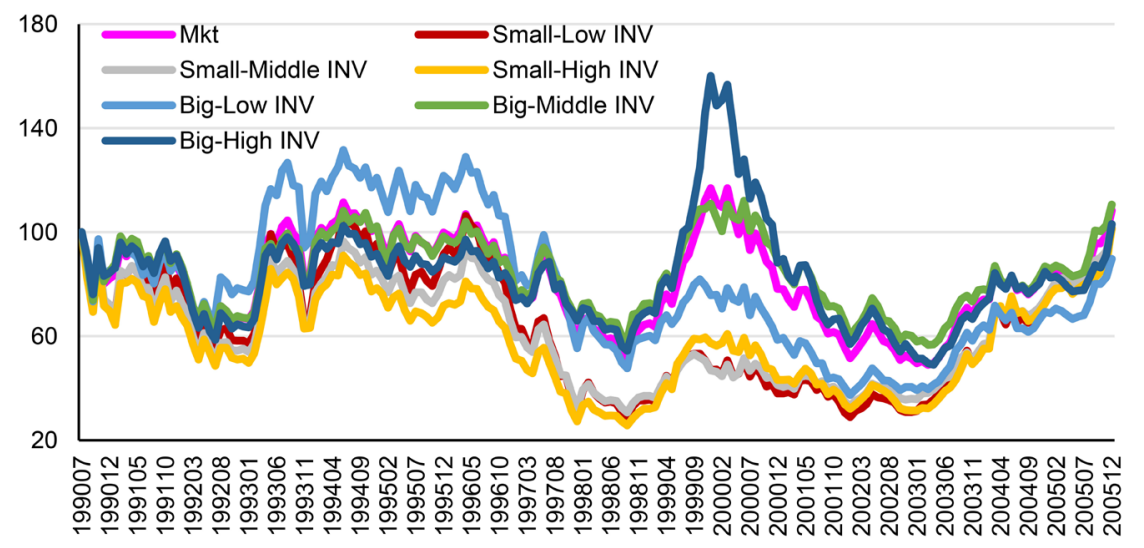

Panel C. January 2006 to October 2020.

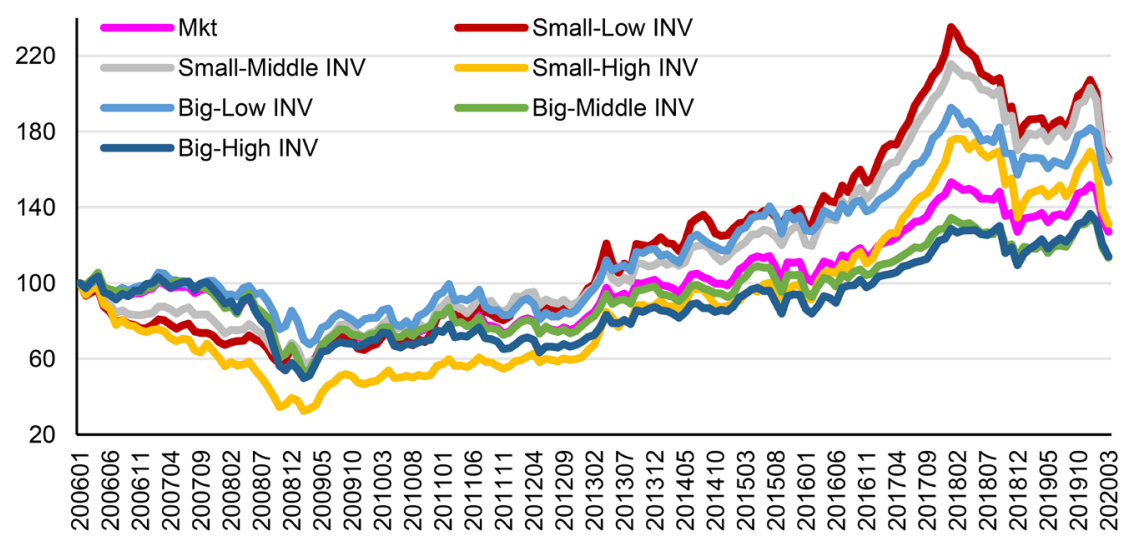

Figure 1. Cumulative raw returns of size- and investment-sorted portfolios in Japan. 
Table 1. Annualized statistics for Japanese size- and investment-sorted portfolio returns and return premia: The case of full and two sub-periods.

\begin{tabular}{|c|c|c|c|c|c|c|c|}
\hline \multicolumn{8}{|c|}{ Panel A. July 1990 to October 2020} \\
\hline & Mkt & $\begin{array}{l}\text { Small- } \\
\text { Low } \\
\text { INV }\end{array}$ & $\begin{array}{l}\text { Small- } \\
\text { Middle } \\
\text { INV }\end{array}$ & $\begin{array}{l}\text { Small- } \\
\text { High } \\
\text { INV }\end{array}$ & $\begin{array}{l}\text { Big- } \\
\text { Low } \\
\text { INV }\end{array}$ & $\begin{array}{l}\text { Big- } \\
\text { Middle } \\
\text { INV }\end{array}$ & $\begin{array}{l}\text { Big- } \\
\text { High } \\
\text { INV }\end{array}$ \\
\hline Return & 3.62 & 5.38 & 4.96 & 5.16 & 3.78 & 3.07 & 3.43 \\
\hline SD & 19.46 & 24.13 & 21.71 & 24.38 & 20.93 & 18.98 & 20.20 \\
\hline Risk premia & 1.08 & 2.84 & 2.42 & 2.61 & 1.24 & 0.53 & 0.89 \\
\hline Sharpe ratio & 0.06 & 0.12 & 0.11 & 0.11 & 0.06 & 0.03 & 0.04 \\
\hline Return premia & 0.00 & 1.76 & 1.34 & 1.53 & 0.16 & -0.55 & -0.19 \\
\hline \multicolumn{8}{|c|}{ Panel B. July 1990 to December 2005} \\
\hline & Mkt & $\begin{array}{l}\text { Small- } \\
\text { Low } \\
\text { INV }\end{array}$ & $\begin{array}{l}\text { Small- } \\
\text { Middle } \\
\text { INV }\end{array}$ & $\begin{array}{l}\text { Small- } \\
\text { High } \\
\text { INV }\end{array}$ & $\begin{array}{l}\text { Big- } \\
\text { Low } \\
\text { INV }\end{array}$ & $\begin{array}{l}\text { Big- } \\
\text { Middle } \\
\text { INV }\end{array}$ & $\begin{array}{l}\text { Big- } \\
\text { High } \\
\text { INV }\end{array}$ \\
\hline Return & 3.27 & 4.91 & 4.16 & 4.59 & 2.61 & 3.01 & 2.99 \\
\hline $\mathrm{SD}$ & 23.50 & 30.19 & 27.11 & 29.10 & 25.95 & 22.20 & 24.02 \\
\hline Risk premia & -0.64 & 0.99 & 0.24 & 0.67 & -1.31 & -0.91 & -0.92 \\
\hline Sharpe ratio & -0.03 & 0.03 & 0.01 & 0.02 & -0.05 & -0.04 & -0.04 \\
\hline Return premia & 0.00 & 1.64 & 0.89 & 1.32 & -0.67 & -0.27 & -0.28 \\
\hline \multicolumn{8}{|c|}{ Panel C. January 2006 to October 2020} \\
\hline & Mkt & $\begin{array}{l}\text { Small- } \\
\text { Low } \\
\text { INV }\end{array}$ & $\begin{array}{l}\text { Small- } \\
\text { Middle } \\
\text { INV }\end{array}$ & $\begin{array}{l}\text { Small- } \\
\text { High } \\
\text { INV }\end{array}$ & $\begin{array}{l}\text { Big- } \\
\text { Low } \\
\text { INV }\end{array}$ & $\begin{array}{l}\text { Big- } \\
\text { Middle } \\
\text { INV }\end{array}$ & $\begin{array}{l}\text { Big- } \\
\text { High } \\
\text { INV }\end{array}$ \\
\hline Return & 3.99 & 5.88 & 5.80 & 5.75 & 5.01 & 3.14 & 3.89 \\
\hline $\mathrm{SD}$ & 14.12 & 15.54 & 14.08 & 18.27 & 13.93 & 14.95 & 15.30 \\
\hline Risk premia & 2.88 & 4.77 & 4.69 & 4.64 & 3.89 & 2.03 & 2.78 \\
\hline Sharpe ratio & 0.20 & 0.31 & 0.33 & 0.25 & 0.28 & 0.14 & 0.18 \\
\hline Return premia & 0.00 & 1.89 & 1.81 & 1.76 & 1.01 & -0.86 & -0.11 \\
\hline
\end{tabular}

Mkt denotes the Japanese overall market; SD denotes standard deviation values.

\section{Data and Methodology}

Basically, our data are monthly Japanese stock portfolios' percentage returns in US dollars, which were all from Fama and French. Our data notations are as follows: Mkt: the market portfolio; Small-Low INV: the small-sized and low investment portfolio; Small-Middle INV: the small-sized and middle (neutral) investment portfolio; Small-High INV: the small-sized and high investment portfolio; Big-Low INV: the big-sized and low investment portfolio; Big-Middle INV: the big-sized and middle (neutral) investment portfolio; and Big-High INV: the big-sized and high investment portfolio. Our research methods are simple statistical and graphical analyses.

This article first examines three sample periods: the full sample period (July 
1990 through to October 2020); the first half sub-period (July 1990 through to December 2005); and the second half sub-period (January 2006 through to October 2020). After that, this article further examines six five-year sub-periods: the Japanese stock price bubble collapse period (July 1990 through to June 1995); the IT bubble period (July 1997 through to June 2002); the period that Japan's Quantitative Easing (QE) raised Japanese stock prices (January 2002 through to December 2006); the period of the US subprime crisis and the Lehman collapse (January 2007 through to December 2011); the period of the Great East Japan Earthquake (April 2010 through to March 2015); and the period of successive monetary easing policies implemented by the Bank of Japan (BOJ) (April 2015 through to March 2020). Furthermore, we also analyze the latest sub-period though not a five-year period (January 2020 through to October 2020).

In Figure 1, the dynamic evolutions of cumulative raw returns as regards the above six Japanese size and investment portfolios and that of the Japanese market portfolio are displayed. In Panels A, B, and C of Figure 1, those for our full period, our first half period, and our second half period are exhibited, respectively (Stock prices are 100 in July 1990 (Panels A and B) and 100 in January 2006 (Panel C)).

\section{Main Results}

Table 1 exhibits key statistics for our full, first half, and second half periods, and Table 2 provides those for our seven sub-periods. Our key results from Table 1 are as follows. 1) For our full period, the highest return is seen in the Small-Low INV portfolio; and the second highest is seen in the Small-High INV portfolio (Panel A). 2) For our first half period, the highest return is shown in the Small-Low INV portfolio; and the second highest is seen in the Small-High INV portfolio (Panel B). 3) For our second half period, the highest is the Small-Low INV portfolio; and the second highest is the Small-Middle INV portfolio (Panel C).

Further, our key results from Table 2 are as follows. 1) For the period including the Japan's stock price bubble and its collapse, the highest return is seen in the Big-Low INV portfolio; and the second highest return is in the Japanese market portfolio (Panel A). 2) For the period of the IT bubble, the highest return is in the Big-High INV portfolio; and the second highest is the Small-High INV portfolio (Panel B). 3) For the period when the BOJ's QE pushed up Japanese stock prices, the highest return is seen in the Small-Low INV portfolio; and the second highest is the Small-Middle INV portfolio (Panel C). 
Table 2. Annualized statistics for Japanese size- and investment-sorted portfolio returns and return premia: The case of seven sub-periods.

\begin{tabular}{lcllllll}
\hline Panel A. July 1990 to June 1995 & & & & \\
\hline & Mkt & $\begin{array}{l}\text { Small- } \\
\text { Low } \\
\text { INV }\end{array}$ & $\begin{array}{l}\text { Small- } \\
\text { Middle } \\
\text { INV }\end{array}$ & $\begin{array}{l}\text { Small- } \\
\text { High } \\
\text { INV }\end{array}$ & $\begin{array}{l}\text { Big- } \\
\text { Low } \\
\text { INV }\end{array}$ & $\begin{array}{l}\text { Big- } \\
\text { Middle } \\
\text { INV }\end{array}$ & $\begin{array}{l}\text { Big- } \\
\text { High } \\
\text { INV }\end{array}$ \\
\hline Return & 2.59 & 2.28 & 0.48 & -1.31 & 6.40 & 2.19 & 0.74 \\
SD & 28.75 & 35.93 & 34.40 & 34.74 & 31.74 & 27.90 & 27.73 \\
Risk premia & -1.84 & -2.15 & -3.95 & -5.74 & 1.97 & -2.24 & -3.69 \\
Sharpe ratio & -0.06 & -0.06 & -0.11 & -0.17 & 0.06 & -0.08 & -0.13 \\
Return premia & 0.00 & -0.31 & -2.11 & -3.90 & 3.81 & -0.40 & -1.85 \\
\hline
\end{tabular}

Panel B. July 1997 to June 2002

\begin{tabular}{|c|c|c|c|c|c|c|c|}
\hline & Mkt & $\begin{array}{l}\text { Small- } \\
\text { Low } \\
\text { INV }\end{array}$ & $\begin{array}{l}\text { Small- } \\
\text { Middle } \\
\text { INV }\end{array}$ & $\begin{array}{l}\text { Small- } \\
\text { High } \\
\text { INV }\end{array}$ & $\begin{array}{l}\text { Big- } \\
\text { Low } \\
\text { INV }\end{array}$ & $\begin{array}{l}\text { Big- } \\
\text { Middle } \\
\text { INV }\end{array}$ & $\begin{array}{l}\text { Big- } \\
\text { High } \\
\text { INV }\end{array}$ \\
\hline Return & -4.86 & -7.27 & -5.78 & -2.20 & -12.38 & -3.32 & -1.86 \\
\hline SD & 23.32 & 31.50 & 26.36 & 29.34 & 25.39 & 21.07 & 26.57 \\
\hline Risk premia & -9.30 & -11.71 & -10.22 & -6.65 & -16.83 & -7.77 & -6.31 \\
\hline Sharpe ratio & -0.40 & -0.37 & -0.39 & -0.23 & -0.66 & -0.37 & -0.24 \\
\hline Return premia & 0.00 & -2.41 & -0.92 & 2.65 & -7.53 & 1.53 & 2.99 \\
\hline \multicolumn{8}{|c|}{ Panel C. January 2002 to December 2006} \\
\hline & Mkt & $\begin{array}{l}\text { Small- } \\
\text { Low } \\
\text { INV }\end{array}$ & $\begin{array}{l}\text { Small- } \\
\text { Middle } \\
\text { INV }\end{array}$ & $\begin{array}{l}\text { Small- } \\
\text { High } \\
\text { INV }\end{array}$ & $\begin{array}{l}\text { Big- } \\
\text { Low } \\
\text { INV }\end{array}$ & $\begin{array}{l}\text { Big- } \\
\text { Middle } \\
\text { INV }\end{array}$ & $\begin{array}{l}\text { Big- } \\
\text { High } \\
\text { INV }\end{array}$ \\
\hline Return & 14.68 & 21.18 & 20.58 & 19.00 & 18.19 & 11.94 & 12.18 \\
\hline $\mathrm{SD}$ & 16.43 & 20.13 & 16.84 & 21.99 & 16.60 & 15.62 & 17.11 \\
\hline Risk premia & 12.39 & 18.88 & 18.29 & 16.70 & 15.89 & 9.65 & 9.88 \\
\hline Sharpe ratio & 0.75 & 0.94 & 1.09 & 0.76 & 0.96 & 0.62 & 0.58 \\
\hline Return premia & 0.00 & 6.49 & 5.90 & 4.31 & 3.51 & -2.74 & -2.51 \\
\hline
\end{tabular}

Panel D. January 2007 to December 2011

\begin{tabular}{lcllllll}
\hline & Mkt & $\begin{array}{l}\text { Small- } \\
\text { Low } \\
\text { INV }\end{array}$ & $\begin{array}{l}\text { Small- } \\
\text { Middle } \\
\text { INV }\end{array}$ & $\begin{array}{l}\text { Small- } \\
\text { High } \\
\text { INV }\end{array}$ & $\begin{array}{l}\text { Big- } \\
\text { Low } \\
\text { INV }\end{array}$ & $\begin{array}{l}\text { Big- } \\
\text { Middle } \\
\text { INV }\end{array}$ & $\begin{array}{l}\text { Big- } \\
\text { High } \\
\text { INV }\end{array}$ \\
\hline Return & -3.72 & 2.85 & 1.97 & -3.46 & -2.20 & -3.68 & -6.69 \\
SD & 16.68 & 16.30 & 15.41 & 20.73 & 16.22 & 18.61 & 18.11 \\
Risk premia & -5.00 & 1.57 & 0.69 & -4.73 & -3.48 & -4.96 & -7.96 \\
Sharpe ratio & -0.30 & 0.10 & 0.04 & -0.23 & -0.21 & -0.27 & -0.44 \\
Return premia & 0.00 & 6.57 & 5.69 & 0.26 & 1.52 & 0.04 & -2.97 \\
\hline
\end{tabular}


Continued

\begin{tabular}{|c|c|c|c|c|c|c|c|}
\hline \multicolumn{8}{|c|}{ Panel E. April 2010 to March 2015} \\
\hline & Mkt & $\begin{array}{l}\text { Small- } \\
\text { Low } \\
\text { INV }\end{array}$ & $\begin{array}{l}\text { Small- } \\
\text { Middle } \\
\text { INV }\end{array}$ & $\begin{array}{l}\text { Small- } \\
\text { High } \\
\text { INV }\end{array}$ & $\begin{array}{l}\text { Big- } \\
\text { Low } \\
\text { INV }\end{array}$ & $\begin{array}{l}\text { Big- } \\
\text { Middle } \\
\text { INV }\end{array}$ & $\begin{array}{l}\text { Big- } \\
\text { High } \\
\text { INV }\end{array}$ \\
\hline Return & 7.85 & 13.68 & 9.66 & 13.57 & 9.31 & 6.83 & 5.74 \\
\hline $\mathrm{SD}$ & 13.21 & 16.66 & 12.68 & 14.97 & 14.64 & 13.03 & 13.46 \\
\hline Risk premia & 7.81 & 13.64 & 9.62 & 13.53 & 9.27 & 6.79 & 5.70 \\
\hline Sharpe ratio & 0.59 & 0.82 & 0.76 & 0.90 & 0.63 & 0.52 & 0.42 \\
\hline Return premia & 0.00 & 5.83 & 1.81 & 5.72 & 1.46 & -1.02 & -2.10 \\
\hline \multicolumn{8}{|c|}{ Panel F. April 2015 to March 2020} \\
\hline & Mkt & $\begin{array}{l}\text { Small- } \\
\text { Low } \\
\text { INV }\end{array}$ & $\begin{array}{l}\text { Small- } \\
\text { Middle } \\
\text { INV }\end{array}$ & $\begin{array}{l}\text { Small- } \\
\text { High } \\
\text { INV }\end{array}$ & $\begin{array}{l}\text { Big- } \\
\text { Low } \\
\text { INV }\end{array}$ & $\begin{array}{l}\text { Big- } \\
\text { Middle } \\
\text { INV }\end{array}$ & $\begin{array}{l}\text { Big- } \\
\text { High } \\
\text { INV }\end{array}$ \\
\hline Return & 3.86 & 5.51 & 7.05 & 7.96 & 4.21 & 2.68 & 4.81 \\
\hline SD & 12.88 & 13.83 & 13.71 & 16.24 & 12.61 & 12.88 & 14.05 \\
\hline Risk premia & 2.81 & 4.45 & 5.99 & 6.90 & 3.15 & 1.63 & 3.75 \\
\hline Sharpe ratio & 0.22 & 0.32 & 0.44 & 0.42 & 0.25 & 0.13 & 0.27 \\
\hline Return premia & 0.00 & 1.64 & 3.18 & 4.09 & 0.34 & -1.18 & 0.95 \\
\hline \multicolumn{8}{|c|}{ Panel G. January 2020 to October 2020} \\
\hline & Mkt & $\begin{array}{l}\text { Small- } \\
\text { Low } \\
\text { INV }\end{array}$ & $\begin{array}{l}\text { Small- } \\
\text { Middle } \\
\text { INV }\end{array}$ & $\begin{array}{l}\text { Small- } \\
\text { High } \\
\text { INV }\end{array}$ & $\begin{array}{l}\text { Big- } \\
\text { Low } \\
\text { INV }\end{array}$ & $\begin{array}{l}\text { Big- } \\
\text { Middle } \\
\text { INV }\end{array}$ & $\begin{array}{l}\text { Big- } \\
\text { High } \\
\text { INV }\end{array}$ \\
\hline Return & 0.18 & -5.42 & -3.82 & 9.30 & -3.78 & -2.38 & 9.76 \\
\hline SD & 18.98 & 23.65 & 22.29 & 29.60 & 18.40 & 19.91 & 19.82 \\
\hline Risk premia & -0.34 & -5.94 & -4.33 & 8.78 & -4.30 & -2.89 & 9.24 \\
\hline Sharpe ratio & -0.02 & -0.25 & -0.19 & 0.30 & -0.23 & -0.15 & 0.47 \\
\hline Return premia & 0.00 & -5.60 & -4.00 & 9.12 & -3.96 & -2.56 & 9.58 \\
\hline
\end{tabular}

Mkt denotes the Japanese overall market; SD denotes standard deviation values.

Moreover, 4) for the period of financial crises, the highest return is recorded in the Small-Low INV portfolio; and the second highest is the Small-Middle INV portfolio (Panel D). 5) For the period including the Great East Japan Earthquake, the highest is the Small-Low INV portfolio; and the second highest is the Small-High INV portfolio (Panel E). 6) For the period of the BOJ's successive monetary easing policies, the highest is the Small-High INV portfolio; and the second highest is the Small-Middle INV portfolio (Panel F). 7) For our latest period reflecting the COVID-19 effect, the highest is the Big-High INV portfolio; and the second highest is the Small-High INV portfolio (Panel G). 


\section{Conclusion}

This article has conducted an overview of the performance of firm size- and firms' investment-sorted stock portfolios in Japan. Using the data in US dollars, we derived key statistics and measures for many sample periods; thus our analysis should be significantly beneficial both for international investors and academic researchers.

As a result of our analysis, the small-size effect was generally clear, and in our second half sub-period, the size effect was particularly clearer; while overall, the effect of firms' investment was not so clear. This suggests that the portfolio constructions sorting by firms' investment are not so effective in Japan. Moreover, as we analyzed the performance of these portfolios by using the data for almost 30 years, our overview presented in this article should be highly informative.

Furthermore, we used the data from Fama and French and in Fama and French (2015), the investment-sorted portfolios are constructed by focusing on the change in total assets from the fiscal year ending in the year before last to the fiscal year ending in the last year (divided by the total assets of the fiscal year ending in the year before last). The matter of portfolio selection is continuously a hot topic as such recent studies as Chen et al. $(2017,2021)$ indicate, and we can use alternative definitions for firms' investment; hence further research of equity portfolios by using some alternative modified measures may be one of our future tasks.

\section{Acknowledgements}

The author is particularly grateful to the repeated cordial article invitation from the Managing Editor, Joy Deng. The author also appreciates a Grant-in-Aid for Scientific Research from the Japan Society for the Promotion of Science and the Chuo University Personal Research Grant for the generous financial assistance to this research. Furthermore, I deeply thank all the editors of this journal for their kind attention to and skillful editorship of my paper.

\section{Conflicts of Interest}

The author declares no conflicts of interest regarding the publication of this paper.

\section{References}

Chen, L., Gao, R., Bian, Y., \& Di, H. (2021). Elliptic Entropy of Uncertain Random Variables with Application to Portfolio Selection. Soft Computing, 25, 1925-1939. https://doi.org/10.1007/s00500-020-05266-Z

Chen, L., Peng, J., Zhang, B., \& Rosyida, I. (2017). Diversified Models for Portfolio Selection Based on Uncertain Semivariance. International Journal of Systems Science, 48, 637-648. https://doi.org/10.1080/00207721.2016.1206985

Fama, E. F., \& French, K. R. (1993). Common Risk Factors in the Returns on Stocks and Bonds. Journal of Financial Economics, 33, 3-56. https://doi.org/10.1016/0304-405X(93)90023-5 
Fama, E. F., \& French, K. R. (1995). Size and Book-to-Market Factors in Earnings and Returns. Journal of Finance, 50, 131-155. https://doi.org/10.1111/j.1540-6261.1995.tb05169.x

Fama, E. F., \& French, K. R. (2015). A Five-Factor Asset Pricing Model. Journal of Financial Economics, 116, 1-22. https://doi.org/10.1016/j.jfineco.2014.10.010

Fama, E. F., \& French, K. R. (2017). International Tests of a Five-Factor Asset Pricing Model. Journal of Financial Economics, 123, 441-463. https://doi.org/10.1016/j.jfineco.2016.11.004

Foye, J. (2018). A Comprehensive Test of the Fama-French Five-Factor Model in Emerging Markets. Emerging Markets Review, 37, 199-222. https://doi.org/10.1016/j.ememar.2018.09.002

Horváth, D., \& Wang, Y. L. (2021). The Examination of Fama-French Model during the Covid-19. Finance Research Letters, forthcoming. https://doi.org/10.1016/j.frl.2020.101848

Huang, T. L. (2019). Is the Fama and French Five-Factor Model Robust in the Chinese Stock Market? Asia Pacific Management Review, 24, 278-289.

https://doi.org/10.1016/j.apmrv.2018.10.002

Mosoeu, S., \& Kodongo, O. (2021). The Fama-French Five-Factor Model and Emerging Market Equity Returns. The Quarterly Review of Economics and Finance, forthcoming. https://doi.org/10.1016/j.qref.2020.10.023

Tsuji, C. (2012). Positive Return Premia in Japan. Quantitative Finance, 12, 345-367. https://doi.org/10.1080/14697688.2010.541485

Tsuji, C. (2020). An Overview of Stock Portfolio Returns and Return Premia in Japan: The Case of Size and Book-to-Market Portfolios. International Journal of Social Science Studies, 8, 39-50. https://doi.org/10.11114/ijsss.v8i4.4885 